\title{
Belfast university reverses record on discrimination
}

\begin{abstract}
Belfast. Three years ago, the reputation of Northern Ireland's oldest university was seriously damaged by charges of discrimination against the Roman Catholic community. The charges were given additional weight by an independent survey published in February. But figures announced last month show that by tightening up of employment practices, Queen's University, Belfast, has achieved a 50 per cent rise in the proportion of Catholics among staff born and educated in Northern Ireland.
\end{abstract}

The university was established in 1845 under an act that specifically prohibited religious discrimination. It was also one of the first employers in Northern Ireland to announce its compliance with fair employment legislation passed in 1976. The local community was therefore particularly shocked by the findings of a three-year investigation by the Fair Employment Agency, published in 1990, which revealed clear evidence of religious discrimination.

Using data from 1987, the agency reported that only a quarter of locally recruited staff came from the Catholic population, which at that time made up 36 per cent of the inhabitants of the local catchment area. The medical faculty was the worst offender; only five per cent of its locally recruited staff were Catholics.

The same trends emerged when the recruitment policies were placed in a broader context. More than half the academic staff are recruited from outside the province; but of those coming from Northern Ireland, 80 per cent of the nonclinical staff (and 95 per cent of the clinical staff) were Protestant.

The publication of the report was followed by a string of tribunal cases brought by individuals claiming religious discrimination. Two of these, settled out of court in June last year for $£ 40,000$, precipitated wide student unrest, and led to a demand from the Catholic population for the resignation of Gordon Beveridge, the vice-chancellor.

In response, Beveridge commissioned an independent investigation into employment practices at the university. The results, published in February this year, confirmed the Fair Employment Agency's conclusions, and made specific recommendations for improvement. It also suggested that the university would have found it difficult to defend the controversial discrimination cases if they had come to trial.

Beveridge immediately accepted the 93 recommendations that arose from the investigation, and acknowledged responsibility for discrimination in the past - moves which helped to head off a further wave of bad publicity. He pointed out that some of

\section{Russia to identify key centres}

Moscow. After long procrastination, the Russian government has finally begun to identify research institutes which are to be known as state scientific centres, and which will benefit from increased budgets and other privileges.

In a decree that has now been issued, President Boris Yeltsin has nominated 33 institutes as state scientific centres (SSC). Although institutes of the Russian Academy of Sciences (RAS) make up a large proportion of those (almost 300 ) seeking this new status, none has yet been chosen.

To be nominated, a research institute must be considered to perform research of great value to the state. Most of the first 33 are applied research institutes such as the Physical Power Institute (Obninsk), the Central State Institute of Aviation (Zhukovskii), the State Optical Institute (St Petersburg) and the Institute of Applied Chemistry.

The new centres are being financed by a special allocation of 57 billion rubles, which translates into a $30-40$ per cent increase of the budgets of the chosen centres, and thus of the salaries of their researchers. Although the new status of SSC has only now been decreed, the Ministry of Science has apparently been paying the extra budgets on its own responsibility since the beginning of the year.

Many directors at the SSCs say that they are now less worried about the survival of their institutes than by the problems caused by the deprivation of the scientific schools, the need to replace obsolete equipment and the freezing of posts at their institutes. Even the comparatively small increase of salaries has apparently been enough to stem the outflow of people, and occasionally to attract newcomers.

The omission of RAS institutes from the first list of SSCs owes less to an objective judgement of their quality than to the resistance of the RAS leadership to the proposal that some institutes should be given special status. But ministry sources expect that the RAS will eventually concede that some of its institutes should be nominated as SSCs, if only because all research institutes must now have more than one source of funds if they are to survive.

Vladimir Pokrovsky

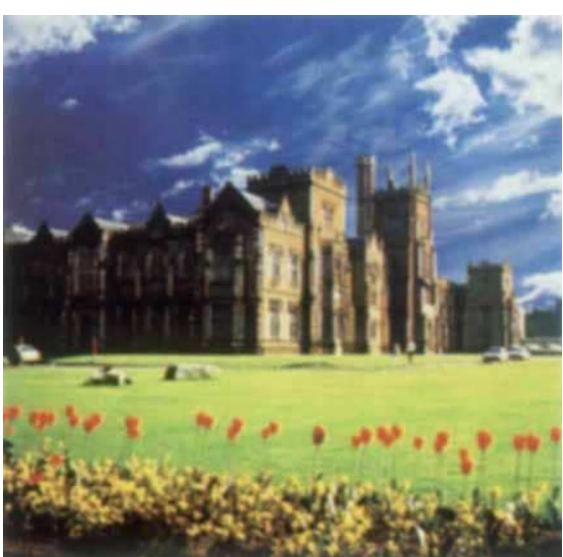

Queen's University, Belfast

the recommendations were already being put into effect; indeed, figures published by the university last month show that the proportion of total staff born and educated in Northern Ireland has risen from 19 to 29 per cent in the past six years.

Beveridge also set up an equal opportunities committee, made up of six nonuniversity members of senate, to oversee the implementation of the recommendations. The changes will be introduced over a period of two years according to a detailed timetable that includes elaborate recruitment procedures and frequent analyses of staff numbers.

The main reason for the situation getting out of hand, according to the investigation, had been a lack of personnel policy. The staff of academic departments wrote their own advertisements, and placed them only in the Protestant press. Since April, all vacancies at the university have been dealt with by the personnel department, and have been advertised in three local newspapers.

Positive discrimination is illegal. But the university is already committed to a greater degree of affirmative action than any other university in the United Kingdom. From June, vacancies in areas where Catholic participation is particularly low have been advertised with a rider specifically encouraging Catholics to apply. And departments have been asked explicitly to consider their own religious bias when choosing between applicants who are otherwise equally qualified.

The prime black spot remains medicine. But close on its tail are the library, and the cleaning and administration departments. Many are unhappy that these departments are not taking seriously enough the requirement for change. Indeed, there has been no significant change in staff ratios in the medical school and libraries.

University officials say that the ability to alter staff ratios is directly related to the rate of staff turnover. But Tim Atwood, director of Belfast's Citizen's Advice Bureau and a member of the university senate, is sceptical. The medical school and library should be called to account and made to justify their poor showing, he says.

Alison Abbott 